Published in final edited form as:

Nat Immunol. 2012 September ; 13(9): 843-850. doi:10.1038/ni.2388.

\title{
TGF- $\beta$ is responsible for NK cell immaturity during ontogeny and increased susceptibility to infection during mouse infancy
}

\author{
Jeffrey P. Marcoe ${ }^{1}$, James R. Lim ${ }^{1}$, Keri L. Schaubert ${ }^{1}$, Nassima Fodil-Cornu ${ }^{2}$, Marsel \\ Matka $^{1}$, Alexandra L. McCubbrey ${ }^{1}$, Alexander R. Farr ${ }^{1}$, Silvia M. Vidal ${ }^{2}$, and Yasmina \\ Laouar $^{1}$ \\ ${ }^{1}$ Department of Microbiology and Immunology, University of Michigan School of Medicine, Ann \\ Arbor, Michigan 48109, USA \\ ${ }^{2}$ Department of Human Genetics, McGill University, Montreal, QC, Canada H3G OB1
}

\begin{abstract}
A major gap in our understanding of infant immunity is why natural killer (NK) cellresponses are deficient, making infants more prone to viral infection. Here we demonstrate that transforming growth factor- $\beta$ (TGF- $\beta$ ) was responsible for NK cell immaturity during infancy. Higher numbers of fully mature NK cells were found in CD11 $\mathrm{c}^{\mathrm{dnR}}$ mice, whose NK cells lack TGF- $\beta \mathrm{R}$ signaling. Importantly, ontogenic maturation of NK cells progressed faster in the absence of TGF- $\beta$ signaling, resulting in the formation of mature NK cell pool early in life. As a consequence, infant $\mathrm{CD} 11 \mathrm{c}^{\mathrm{dnR}}$ mice efficiently controlled viral infections. These data thus demonstrate an unprecedented role for TGF- $\beta$ in ontogeny that can explain why NK cell responses are deficient early in life.
\end{abstract}

\section{INTRODUCTION}

The ability of natural killer (NK) cells to respond rapidly without prior sensitization places them at the front line of defense against infection ${ }^{1}$. This attribute largely depends on their ability to sense and kill virus-infected cells ${ }^{2}$. Detection of virus-infected cells is ensured by a repertoire of germ line-encoded receptors specialized in the recognition of stress ligands as well as decreased abundance of major histocompatibility complex (MHC) class I molecules ${ }^{3}$. Once in contact with infected cells, NK cells rapidly secrete granzymes and perforins to control viral spread within hours of infection ${ }^{4,5}$. The program of such rapid cytotoxicity requires that NK cells are armed with pre-existing stocks of granzymes and

\footnotetext{
Users may view, print, copy, download and text and data- mine the content in such documents, for the purposes of academic research, subject always to the full Conditions of use: http://www.nature.com/authors/editorial_policies/license.html\#terms

Correspondence should be addressed to Y.L. (ylaouar@umich.edu). Yasmina Laouar, Ph.D., Med Sci II 6605D, 1150 West Medical Center Drive, Ann Arbor, MI 48109-0620, Phone: (734)615-2248, Fax: (734) 615-6060.

COMPETING FINANCIAL INTERESTS

No conflict of interest

AUTHOR CONTRIBUTIONS

J.P.M., J.R.L., K.L.S., M.M, and A.R.F. performed and analyzed experiments; A.L.M. conducted microarray experiments; N.F.C. performed MCMV plaque assay; S.M.V. provided reagents and advice on MCMV experiments; Y.L. designed experiments, analyzed data, and wrote the manuscript.
} 
perforins mRNA. Collective results suggest that this program is initiated during the development of NK cells and that pre-arming of NK cells is completed at the terminal step of maturation ${ }^{6,7}$. In that regard, NK cells possess a unique developmental pathway when compared to other cytotoxic lymphocytes.

Development of NK cells requires three major steps, including commitment to NK cell lineage, establishment of NK cell education and acquisition of NK cell maturation ${ }^{8}$. The first step $(\mathrm{pNK})$ is the acquisition of interleukin 2 receptor $\beta$ (IL-2R $\beta$, stage $\mathrm{A})^{9}$ although another progenitor lacking IL-2R $\beta$ has been recently identified upstream pNK cells ${ }^{10}$. The next step requires up-regulation of NK1.1 and delineates the immature stage ${ }^{11}$. At this stage, immature NK cells (iNK) initiate expression of MHC class I-recognition receptors encoded by Ly49 genes. Two stages of iNK cells are distinguished based on differential expression of inhibitory and activating Ly49 receptors (stage B-C) ${ }^{12}$. Subsequently, NK cells up-regulate CD49b (DX5) and enter the maturation process ${ }^{11}$. Maturation of NK cells (mNK) is completed in three stages based on progressive expression of CD11b and CD43: stage D $\left(\mathrm{CD} 11 \mathrm{~b}^{-} \mathrm{CD} 43^{-}\right)$, the least mature; stage $\mathrm{E}\left(\mathrm{CD} 11 \mathrm{~b}^{+} \mathrm{CD} 43^{-}\right)$, intermediate; and stage $\mathrm{F}$ $\left(\mathrm{CD} 11 \mathrm{~b}^{+} \mathrm{CD} 43^{+}\right)$, representing the terminal step of NK cell maturation. The molecular events that drive NK cell maturation have been extensively studied and collective results have identified several positive regulators, including IL-15Ra ${ }^{13}$, T-bet ${ }^{14}$, GATA-3 (ref. 15), IRF-2 (ref. 16), $\mathrm{MEF}^{17}$, MITF ${ }^{18}$, and CEBP- ${ }^{19}$. Although the NK cell field made great advances in deciphering the mechanisms driving NK cell maturation, a remaining major issue lies unresolved: Why do NK cells fail to complete maturation early in life?

Immaturity of NK cells in neonates and infants represents an underlying factor for increased susceptibility to infection early in life ${ }^{20-22}$. Most reports converge to show that NK cell responses are strongly reduced in neonates and infants, as indicated by decreased numbers of cytoplasmic granules, poor degranulation ability, and impaired release of lytic factors ${ }^{23,24}$. Moreover, the ability of transferred adult NK cells to protect neonate mice from murine cytomegalovirus (MCMV) infection provides clear evidence of impaired NK cell function $^{25}$. Collectively, the current assumptions support the notion that immaturity of NK cells during early life is the result of intrinsic deficiency ${ }^{20-24}$. Instead, we found that this defect is orchestrated by an extrinsic factor, transforming growth factor- $\beta$ (TGF- $\beta$ ). We provide direct evidence that TGF- $\beta$ was the factor responsible for NK cell immaturity during ontogeny and increased susceptibility to infection during infancy. We demonstrate that NK cells could complete maturation early in life if TGF- $\beta$ R signaling was blocked, indicating plasticity of NK cell maturation during ontogeny. It is therefore tempting to propose the functional inactivation of TGF- $\beta$ R signaling as a strategy to reverse NK cell deficit to improve infant responses to infection.

\section{RESULTS}

\section{Production of NK cells is under control of TGF- $\beta$}

One major consequence from the lack of TGF- $\beta R$ signaling in innate cells $\left(C D 11 c^{\mathrm{dnR}}\right.$ mice) was the generation of a larger pool of mature NK cells in the periphery ${ }^{26}$. Specifically, mature NK cells from spleen, blood and liver were found 5-10 times more abundant in CD11 $c^{\mathrm{dnR}}$ mice compared to control littermates ${ }^{26}$. Our finding that TGF- $\beta$ limits NK cell 
number raised a central question: Is TGF- $\beta$ R signaling required at a precursor stage (production) or at a mature level (homeostasis)? To address this question, we used a hematopoietic stem cell culture approach and directly assessed the effect of TGF- $\beta$ on NK cell production (Fig. 1). NK cell production from multipotent stem cells can be recapitulated in vitro through two steps of differentiation ${ }^{27}$. In the first step (days 0-5), bone marrowenriched multipotent stem cells $\left(\mathrm{Lin}^{-} \mathrm{Sca}-1^{+} \mathrm{ckit}^{+}\right)$were cultured in the presence of Flt3L, SCF and IL-7 to generate the first committed NK cell progenitors $\left(\mathrm{CD} 122^{+} \mathrm{NKG}^{2} \mathrm{D}^{+}\right)$. In the second step (days 5-11), NK cell progenitors were driven to differentiate subsequently into immature $\left(\mathrm{CD} 122^{+} \mathrm{NK} 1.1^{+}\right)$and mature $\left(\mathrm{NK} 1.1^{+} \mathrm{DX} 5^{+}\right) \mathrm{NK}$ cells under the influence of IL-15 and OP9 stromal cells. To determine the role of TGF- $\beta$ during NK cell production, cultures were treated with TGF- $\beta$ on day 8 and outcomes were assessed on day 11 (Fig. $1 \mathrm{a}, \mathrm{b})$. We found that addition of TGF- $\beta$ severely blocked the derivation of mature NK cells from wild-type precursors as demonstrated by $20-40$ fold decrease in the number of NK1.1 ${ }^{+} \mathrm{DX} 5^{+}$cells $($Fig. 1a,b). This finding provides the first line of evidence that TGF- $\beta$ limits NK cell number at a precursor stage.

\section{TGF- $\beta$ controls terminal step of NK cell maturation}

If TGF- $\beta$ limits NK cell number at a precursor stage, then at what stage does the control by TGF- $\beta$ occur? To identify such a putative stage, development of TGF- $\beta$-resistant NK cells was dissected in vivo using $\mathrm{CD} 11 \mathrm{c}^{\mathrm{dnR}}$ mice (Fig. 2). Based on the current map of NK cell development ${ }^{8}$, we examined four stages identified by the hematopoietic stem cells (HSCs), the earliest NK cell precursors (pNK), the immature (iNK) and mature (mNK) NK cells. Phenotypic identification of each stage is described in Supplementary Fig. 1. We quantitated the numbers of each cell subset, however no significant changes were found for HSCs, pNK or iNK cells (Fig. 2a). In contrast, analysis of mNK cell compartment in CD11 $\mathrm{c}^{\mathrm{dnR}}$ mice revealed increased numbers of mature NK cells at the terminal differentiation stage in the bone marrow (Fig. 2b,f).

Distribution of CD11b versus CD43 among wild-type mNK cells showed a majority of cells at stage $\mathrm{D}$ and $\mathrm{E}$, but only fewer were detected at stage $\mathrm{F}$. In sharp contrast, mNK cells that developed in the absence of TGF- $\beta$ R signaling were found predominantly at stage F (Fig. $2 \mathrm{~b}, \mathrm{f})$. This finding was demonstrated by augmented frequency of $\mathrm{CD} 11 \mathrm{~b}^{+} \mathrm{CD} 43^{+} \mathrm{mNK}$ cells in the bone marrow of CD11 $c^{\mathrm{dnR}}$ mice (Fig. 2b). Such increases translated into 10-fold gain in numbers of terminally mature NK cells produced in the absence of TGF- $\beta$ R signaling (Fig. 2c). Importantly, enhanced maturation of TGF- $\beta$-resistant NK cells as identified by upregulation of CD43 was further confirmed by the loss of CD27, another marker commonly used to identify terminally mature NK cells ${ }^{28}$ (Fig. 2d,e and Supplementary Fig. 2). To ascertain this finding, we performed parallel analysis in BALB/c strain and confirmed higher production of terminally mature NK cells in the absence of TGF- $\beta$ R signaling (Supplementary Fig. 3). To extend this finding, we examined the relationship between numbers of $\mathrm{CD} 11 \mathrm{~b}^{+} \mathrm{CD} 43^{+} \mathrm{mNK}$ cells produced in the bone marrow versus numbers established in the spleen (Fig. 2f). As predicted, we observed proportional increases in the spleen, indicating that increased NK cell numbers in the spleen of CD11 $\mathrm{c}^{\mathrm{dnR}}$ mice was the result of augmented NK cell production from the bone marrow. Notably, all CD11 ${ }^{+} \mathrm{CD} 43^{+}$ mNK cells from CD11 $c^{\mathrm{dnR}}$ mice expressed NKp46 (ref. 29), indicating that these cells are 
bona fide terminally mature NK cells (Supplementary Fig. 4). Collectively, these data demonstrate that TGF- $\beta$ is a checkpoint at the terminal step of NK cell maturation and a determining factor of NK cell production from the bone marrow.

\section{TGF- $\beta$-resistant $\mathrm{mNK}$ cells dominate in cellular competition}

To ascertain that augmented NK cell maturation in $\mathrm{CD} 11 \mathrm{c}^{\mathrm{dnR}}$ mice is cell-autonomous, we re-examined the development of TGF- $\beta$-resistant NK cells in mixed bone marrow chimeras (Fig. 3). In the first set of experiments, mixed bone marrow chimeras were constructed using 1:1 ratio of wild-type $\left(\mathrm{CD} 45.2^{+}\right)$and $\mathrm{CD} 11 \mathrm{c}^{\mathrm{dnR}}\left(\mathrm{CD} 45.1^{+}\right)$donor cells, and development of NK cells was compared from both sources in the same environment (Fig. 3a,b). We found that $\mathrm{NK}$ cell development from $\mathrm{CD} 11 \mathrm{c}^{\mathrm{dnR}}$ origin produced abundant $\mathrm{mNK}$ cells at stage $\mathrm{F}$ (Fig. 3b), a phenotype reminiscent of increased NK cell production in $\mathrm{CD} 11 \mathrm{c} \mathrm{dnR}^{\mathrm{m}}$ mice (Fig. 2b). In direct comparison, the development of NK cells from wild-type donor cells generated many fewer mNK cells at stage F (Fig. 3b), consistent with normal NK cell production in wild-type mice (Fig. 2b). Notably, NK cells arising in the bone marrow were proportionally established in the periphery, as demonstrated by dominance of TGF- $\beta$-resistant NK cells over controls despite equal chimerism (Supplementary Fig. 5a).

In the second set of experiments, we constructed mixed bone marrow chimeras with dominant fractions of wild-type donor cells and asked whether TGF- $\beta-$ resistant $\mathrm{mNK}$ cells can override under these limiting conditions (Fig. 3c,e). To this aim, mixed bone marrow chimeras were constructed with wild-type $\left(\mathrm{CD} 45.2^{+}\right)$and $\mathrm{CD} 11 \mathrm{c} \mathrm{dnR}\left(\mathrm{CD} 45.1^{+}\right)$donor cells provided in the inoculum at 1:1, 2:1, 4:1 and 9:1 ratios (Fig. 3c). Six weeks post-transfer, cellular chimerism was examined along NK cell development as illustrated in Supplementary Fig. 5b. As expected, bone marrow inoculum proportionally established chimerism in pNK and iNK cell compartments, reflecting dominance of wild-type origin (Fig. 3e). However, as developing NK cells progressed through maturation, cellular chimerism gradually reversed, culminating by dominance of TGF- $\beta-$ resistant $\mathrm{mNK}$ cells at stage F (Fig. 3d,e).

Two major points emerged from these experiments. First, normal numbers of wild-type $\mathrm{CD} 11 \mathrm{~b}^{+} \mathrm{CD} 43^{+} \mathrm{mNK}$ cells arising from 1:1 bone marrow ratios in the mixed chimeras showed that augmented production from $\mathrm{CD} 11 \mathrm{c}^{\mathrm{dnR}}$ origin was cell-intrinsic, not microenvironment dependent. Secondly, the dominance of transgenic CD11 b $\mathrm{CD}^{+} 43^{+} \mathrm{mNK}$ cells in 9:1 ratios of wild-type to $C D 11 c^{\mathrm{dnR}}$ bone marrow chimeras suggested that bone marrow production of mature NK cells is far superior in the absence of TGF- $\beta$.

\section{Signals downstream TGF- $\beta$ that limit NK cell maturation}

To elucidate how TGF- $\beta$ controls NK cell production, we first examined proliferation upon maturation (Fig. 4). It has been shown that substantial proliferation occurs in developing NK cells while they are still immature. However, further proliferation wanes in mature NK cells ${ }^{11}$. Based on this model, we hypothesized that TGF- $\beta$ limits NK cell production via cell cycle arrest at terminal maturation. Consistent with previous studies, we found that 5bromodeoxyuridine (BrdU) staining in wild-type mice severely declined during iNK to mNK transition (Fig. 4a,c). In sharp contrast, TGF- $\beta$-resistant NK cells exhibited enhanced 
proliferation upon maturation, resulting in maximum cell numbers at mNK stage (Fig. 4a,c). To determine which population accounted for the increased proliferation of TGF- $\beta$-resistant $\mathrm{mNK}$ cells, we examined the distribution of BrdU staining upon acquisition of $\mathrm{CD} 11 \mathrm{~b}$ versus CD43 (Fig. 4a,b). We found increased proliferation of stage D and E TGF- $\beta$-resistant mNK cells, rather than proliferation of stage F cells (Fig. 4d).

Next, to identify target genes, we used a cell cycle specific array and examined changes associated with lack of TGF- $\beta$ R signaling along NK cell maturation (Fig. 4e). Among 25 cell cycle-related genes, two genes $-C d c 7$ and $p 21$-emerged as candidates associated with increased proliferation of TGF- $\beta$-resistant $\mathrm{mNK}$ cells at stages $\mathrm{D}$ and $\mathrm{E}$. Increased cell cycle at stage $\mathrm{D}$ was associated with up-regulation of $\mathrm{Cdc} 7$ (a protein kinase essential for initiation of DNA replication) ${ }^{30}$ while robust proliferation at stage $\mathrm{E}$ correlated with down-regulation of p21 (an inhibitor of cell cycle progression to G1) ${ }^{31}$. Notably, no changes were observed at stage F, confirming results above (Fig 4d).

Because substantial proliferation occurred at stage E, but cells accumulated at stage F, we reasoned that NK cell transition from stage $\mathrm{E}$ to $\mathrm{F}$ must be facilitated in the absence of TGF$\beta R$ signaling. To test this hypothesis, we examined the expression of T-bet, GATA-3, and IRF-2, three transcription factors known to govern NK cell transition to terminal maturation ${ }^{14-16}$ (Fig. 4f). Compared to control cells, TGF- $\beta$-resistant mNK cells showed 8 10 fold increase in T-bet and GATA-3 mRNA abundance at stage F. Notably, no significant changes were observed at stages D and E, indicating a selective role of TGF- $\beta$ in limiting Tbet and GATA-3 upon terminal maturation of NK cells. To further confirm this finding, mature NK cells were treated with exogenous TGF- $\beta$ and T-bet and GATA-3 expression was determined by quantitative RT-PCR (Supplementary Fig. 6). Similar to T cells ${ }^{32}$, we found that TGF- $\beta$ was a potent suppressor of T-bet and GATA-3 expression in NK cells. Based on these data, we conclude that TGF- $\beta$ limits NK cell production by arresting NK cell cycle at stages $\mathrm{D}$ and $\mathrm{E}$ via $\mathrm{Cdc} 7$ and $\mathrm{p} 21$ and by limiting NK cell transition to stage $\mathrm{F}$ via $\mathrm{T}$ bet and GATA-3.

\section{Efficient maturation of NK cells in CD11c dnR infants}

Immaturity of the immune system, including incomplete NK cell maturation, is one major limitation of early life in both humans and mice ${ }^{33,34}$. In this context, our finding that TGF- $\beta$ limits NK cell maturation raised a key question: Is TGF- $\beta$ R signaling responsible for NK cell immaturity during ontogeny? To address this question, we examined NK cell maturation during ontogeny and determined outcomes of lack of TGF- $\beta$ R signaling at three stages of NK cell life ${ }^{35,36}$ : neonatal (0-10 days), infant (17-25 days), and adult (=56 days)(Fig. 5).

Strikingly, we found that acquisition of NK cell maturation during ontogeny occurred differently in CD11 $\mathrm{c}^{\mathrm{dnR}}$ mice, as $\mathrm{mNK}$ cells progressed faster in the absence of TGF- $\beta \mathrm{R}$ signaling (Fig. 5a,b). Specifically, kinetics of the numbers of $\mathrm{CD} 11 \mathrm{~b}^{+} \mathrm{CD} 43^{+} \mathrm{mNK}$ cells revealed substantial maturation in $\mathrm{CD} 11 \mathrm{c}^{\mathrm{dnR}}$ pups as early as 10 days of age. At this age, wild-type NK cells failed to complete terminal maturation, as demonstrated by the lack of $\mathrm{CD} 11 \mathrm{~b}^{+} \mathrm{CD} 43^{+} \mathrm{mNK}$ cells at both neonate and infant stages (Fig. 5b,c). Terminally mature NK cells were detected in adult wild-type mice, as expected, but numbers produced at 56 days of age were found equivalent to those obtained from $\mathrm{CD} 11 \mathrm{c}^{\mathrm{dnR}}$ mice at 10 days of age 
(Fig. 5b,c). Analysis of the spleen provided another demonstration that ontogenic maturation of NK cells progressed faster in the absence of TGF- $\beta$ R signaling (Fig. 5b,c). At 10 days of age, none of wild-type $\mathrm{mNK}$ cells completed terminal maturation, while $25 \%$ of TGF- $\beta$ resistant $\mathrm{mNK}$ cells were identified at stage F. At 20 days of age, only few stage F-mNK cells emerged in wild-type spleen, while $50 \%$ of $\mathrm{mNK}$ cells in CD11 $\mathrm{c}^{\mathrm{dnR}}$ mice have already completed terminal maturation. At 56 days of age, optimum terminal maturation was reached in both mouse groups but with 10 -fold increase in numbers recovered from CD11 $\mathrm{c}^{\mathrm{dnR}}$ versus wild-type spleens.

To better characterize the ontogenic maturation of TGF- $\beta$-resistant NK cells, infant $\mathrm{CD} 11 \mathrm{c}^{\mathrm{dnR}}$ mice were examined for early acquisition of NK cell receptors (Fig. 6). Since the acquisition of NK cell receptors precedes NK cell maturation ${ }^{37}$, we asked whether TGF- $\beta$ has a role in the acquisition of NK cell receptors at early age. Regardless of their age, we found that $\mathrm{mNK}$ cells exhibited similar NK cell receptor expression in CD11 $\mathrm{c}^{\mathrm{dnR}}$ versus wild-type mice, indicating that early acquisition of NK cell receptors was not controlled by TGF- $\beta$ R signaling (Fig. 6a,b and Supplementary Fig. 7a). However, the segregation of NK cell receptors on the basis of CD43 marker provided a powerful tool to conclusively demonstrate early maturation of NK cells in infant CD11 $\mathrm{c}^{\mathrm{dnR}}$ mice (Fig. 6a,c and Supplementary Fig. 7b). These data provide direct evidence that TGF- $\beta$ is responsible for NK cell immaturity during ontogeny.

\section{Protection of CD11 $c^{\mathrm{dnR}}$ infants from MCMV infection}

Consistent with faster maturation of TGF- $\beta$-resistant NK cells (Fig. 7a,b), infant CD11c $c^{\mathrm{dnR}}$ mice showed resistance to MCMV, while wild-type littermates succumbed to infection as expected (Fig. 7c). Susceptibility of infant wild-type mice was demonstrated by high viral titers (Fig. 7c) as well as severe lymphopenia (Supplementary Fig. 8). In sharp contrast, infection of infant $\mathrm{CD} 11 \mathrm{c}^{\mathrm{dnR}}$ mice resulted in strong reduction of viral titers, indicating efficient control of MCMV infection (Fig. 7c). Control of MCMV infection in adult mice has been shown to be dependent on robust proliferation of $\mathrm{Ly}_{49 \mathrm{H}^{+}} \mathrm{NK}$ cell subset ${ }^{11,38-40}$. Thus, we asked whether protection from MCMV in infant CD11 $\mathrm{c}^{\mathrm{dnR}}$ mice was associated with proliferation of $\mathrm{Ly}_{4} 9 \mathrm{H}^{+} \mathrm{NK}$ cells. In this case, infected infant mice were treated with BrdU and frequency of cycling cells was determined among $\mathrm{Ly}_{4} 9 \mathrm{H}^{-}$versus $\mathrm{Ly} 49 \mathrm{H}^{+} \mathrm{NK}$ cell subsets (Fig. 7d,e). $\mathrm{Ly}_{49 \mathrm{H}^{+}} \mathrm{NK}$ cells from infant CD11 $\mathrm{c}^{\mathrm{dnR}}$ mice exhibited robust proliferation, consistent with resistance to MCMV infection (Fig. 7e). In contrast, $\mathrm{Ly}_{49 \mathrm{H}^{+}}$ NK cells from infant wild-type littermates failed to proliferate in response to MCMV, consistent with NK cell immaturity and viral susceptibility during infancy.

\section{DISCUSSION}

One major gap in the current map of NK cell development is that signals that limit NK cell generation remain unknown. The process of generating NK cells is tightly controlled and results from a balance between extracellular signals that cooperate with optimal amounts of transcription factors ${ }^{8}$. These factors can be divided in two groups based on the current map of NK cell development: IL-2R, PU.1, and ID2 are required for NK cell commitment, while 
IL-15Ra, T-bet, GATA-3, and IRF-2 promote NK cell maturation. Here, we show that TGF$\beta$ is a negative regulator of NK cell maturation.

What signals limit NK cell production at stage F? The distribution of NK cells in the bone marrow revealed that most mNK cells are identified at stages D and E, but fewer are detected at stage F. Based on this, we postulated that mechanisms of negative regulation must operate at the transition to terminal maturation. This study provided several lines of evidence supporting this hypothesis. First, lack of TGF- $\beta R$ signaling in CD11c ${ }^{\mathrm{dnR}}$ mice uncovered massive production of terminally mature NK cells as identified by up-regulation of CD43 (ref. 11) and loss of CD27 (ref. 28). Second, parallel analysis of CD11 $\mathrm{c}^{\mathrm{dnR}}$ mice on $\mathrm{BALB} / \mathrm{c}$ background confirmed that development of NK cells in the absence of TGF- $\beta R$ signaling results in high production at terminal maturation. Third, outcomes of cellular competition in mixed bone marrow chimeras conclusively demonstrated that augmented production of stage F-mNK cells from $\mathrm{CD} 11 \mathrm{c}^{\mathrm{dnR}}$ origin is cell-autonomous. These data provide evidence that TGF- $\beta$ imposes constraints at the terminal step of NK cell maturation as a means of controlling NK cell production from the bone marrow.

We found that control by TGF- $\beta$ occurs at two levels upon NK cell maturation. The first checkpoint is to prevent cell cycle as developing NK cells progress through maturation. Results from $\mathrm{CD} 11 \mathrm{c}^{\mathrm{dnR}}$ mice revealed significant proliferation as TGF- $\beta$-resistant NK cells progressed through maturation. This massive proliferation was not the result of cell cycle at stage $\mathrm{F}$ but instead accounts for cell cycle at stages D-E. In an attempt to define the molecular mechanism, we referred to previous studies of TGF- $\beta$ cytostatic function ${ }^{41,42}$. Based on these studies, we identified a set of TGF- $\beta$ response genes that can promote cell cycle arrest upon NK cell maturation: At the core of this set are the activation of p21 and the inhibition of Cdc7. The notion that proliferation of developing NK cells wanes upon maturation was previously reported ${ }^{11}$. The point of particular interest here is the demonstration that TGF- $\beta$ is the signal that promotes cell cycle arrest as developing NK cells progress through maturation.

The observation that transition to stage $\mathrm{F}$ correlates with high amounts of T-bet and GATA-3 in CD11 $c^{\mathrm{dnR}}$ mice identifies the second checkpoint by TGF- $\beta$. Transition to terminal maturation depends on three transcription factors, namely T-bet ${ }^{14}$, GATA-3 (ref. 15), and IRF-2 (ref. 16). Accumulated data from mutant mice showed that NK cells deficient in T-bet, GATA-3, or IRF-2 share the same abnormality, as demonstrated by a blockade at $\mathrm{CD} 11 \mathrm{~b}^{\text {low }} \mathrm{CD} 43^{\text {low }}$ stage (stage D-E) associated with functional defects ${ }^{8,14-16}$. By comparison, we found that development of NK cells in the absence of TGF- $\beta$ R signaling results in massive production at $\mathrm{CD} 11 \mathrm{~b}^{+} \mathrm{CD} 43^{+}$stage (stage $\mathrm{F}$ ), and this gain correlated with high expression of T-bet and GATA-3. Our data support a model in which T-bet and GATA- 3 promote NK cell transition to terminal maturation while TGF- $\beta$ imposes constraints on both transcription factors to control outcomes of NK cell production from the bone marrow. This model is further supported by the observation showing: (i) that TGF- $\beta$ is a potent suppressor of T-bet and GATA-3 in T cells ${ }^{32}$, (ii) that TGF- $\beta$ can efficiently suppress T-bet and GATA-3 in NK cells, and (iii) that ectopic expression of high amounts of $\mathrm{T}$-bet in precursor cells correlates with augmented production of mature NK cells ${ }^{14}$. The role of T-bet and GATA-3 in NK cells triggered extensive interest because, unlike T cells, 
NK cells express and require both transcription factors to complete maturation. Here, we show that outcomes of terminal maturation result from the interplay between TGF- $\beta$ and transcription factors T-bet and GATA-3. Such instructive role of TGF- $\beta$ upstream of T-bet and GATA-3 identifies a new signaling axis in determining the fate of NK cell maturation.

Still, the scope of this study is the demonstration that deficient NK cell maturation during infancy is the result of TGF- $\beta$ signal. Analysis of NK cell maturation during ontogeny provided clear evidence that NK cells fail to complete maturation in early life. To our surprise, we discovered that NK cells can complete maturation as early as 10 days of age if TGF- $\beta R$ signaling is blocked. As a result, CD11 $c^{\mathrm{dnR}}$ mice featured mature NK cell compartment at early age, while the formation of mature NK cell pool in wild type mice was delayed until adult age. One important consequence of this phenotype was efficient control of viral infection in $\mathrm{CD} 11 \mathrm{c}^{\mathrm{dnR}}$ infant mice. Protection of $\mathrm{CD} 11 \mathrm{c} \mathrm{cnR}^{\mathrm{nn}}$ infant mice from MCMV infection was demonstrated by significant reduction of viral titers and robust proliferation of $\mathrm{Ly} 49 \mathrm{H}^{+} \mathrm{NK}$ cells, a cell subset that specifically recognizes the $\mathrm{m} 157$ glycoprotein encoded by MCMV ${ }^{11,38-40}$. In contrast, $\mathrm{Ly} 49 \mathrm{H}^{+} \mathrm{NK}$ cells from wild type pups failed to proliferate in response to MCMV, although $\mathrm{Ly} 49 \mathrm{H}^{+} \mathrm{NK}$ cells from wild type adult mice are capable of efficient proliferation ${ }^{11}$. Nevertheless, earlier work provided evidence that NK cell proliferation from adult mice can be suppressed by TGF- $\beta$ in response to lymphocytic choriomeningitis virus (LCMV) infection ${ }^{43,44}$. In agreement with our finding, most reports converge to show that NK cell functions are strongly reduced in early life 23,24 . In this context, our data demonstrate an unprecedented role for TGF- $\beta$ in ontogeny that explains why NK cell responses are deficient early in life.

We do not know the exact source of TGF- $\beta$ during ontogeny, but one mechanism could arise from the high activity of regulatory $\mathrm{T}$ cells (Treg) in early childhood ${ }^{45,46}$. Indeed, increased activity of Treg cells in early life is undisputable as it is demonstrated by high numbers of Treg cells as well as potent immunosuppressive activity in the cord blood ${ }^{45,46}$. Such an immunosuppressive environment would be critical in preventing deleterious inflammation in early life. The consequence, however, is immaturity of NK cells and increased susceptibility to infection. Thus, our study contributes to the evolution of the current model of NK cell development by adding TGF- $\beta$ as a critical determinant of NK cell maturation during ontogeny.

\section{METHODS}

\section{Mice and Mixed BM Chimeras}

$\mathrm{CD} 11 \mathrm{c}^{\mathrm{dnR}}$ mice are transgenic mice expressing a dominant negative form of TGF- $\beta$ receptor type II under the control of the promoter of $\mathrm{CD} 11 \mathrm{c}^{26}$. CD $11 \mathrm{c}^{\mathrm{dnR}}$ mice were maintained under pure $\mathrm{C} 57 \mathrm{BL} / 6$ and $\mathrm{BALB} / \mathrm{c}$ backgrounds at the University of Michigan. All experiments described in Figures 1-7 were conducted using $\mathrm{CD} 11 \mathrm{c}^{\mathrm{dnR}}$ mice under pure C57BL/6 background. To generate mixed bone marrow chimeras, C57BL/6 recipient mice were lethally irradiated (1000 rad) and transplanted (i.v.) with $10^{6}$ donor bone marrow cells containing mixtures of CD11 $\mathrm{c}^{\mathrm{dnR}}(\mathrm{CD} 45.1)$ and wild-type (CD45.2) bone marrow donor cells provided at different ratios. Congenic CD45.2 and CD45.1 C57BL/6 mice were obtained from Jackson Laboratories. All mice were maintained in a specific pathogen-free 
barrier unit at the University of Michigan. All experiments followed guidelines of the University of Michigan Animal Care and Use Committee, and approval for use of rodents was obtained from the University of Michigan according to criteria outlined in the Guide for the Care and Use of Laboratory Animals from the National Institutes of Health.

\section{In vitro Generation of NK cells}

The generation of NK cells from stem cell precursors was conducted in vitro, based on protocol previously described ${ }^{27}$. Briefly, CD11 $\mathrm{c}^{\mathrm{dnR}}$ and wild-type mice were first treated (i.p.) with 5-FU (5-Fluorouracil; Sigma) provided at $150 \mathrm{mg} / \mathrm{kg}$ body weight ${ }^{47}$. Four days later, mice were sacrificed and HSC-enriched bone marrow cells were cultured at 10,000 cells/well in complete RPMI supplemented with $0.5 \mathrm{ng} / \mathrm{ml}$ murine IL-7 (PeproTech), 30 $\mathrm{ng} / \mathrm{ml}$ mouse SCF (PeproTech), and $100 \mathrm{U} / \mathrm{ml}$ murine Flt3L (eBiosciences). Cells were refed with the same media on day 3 . On day 5 , cultures were harvested and re-plated at $15,000 /$ well on a confluent monolayer of OP9 stromal cells in complete RPMI containing 30 $\mathrm{ng} / \mathrm{ml}$ murine IL-15 (PeproTech). On day 8, cultures were re-fed with the same media with or without $5 \mathrm{ng} / \mathrm{ml}$ human TGF- $\beta$ (R\&D Systems). On day 11, cells were harvested and analyzed by flow cytometry.

\section{Flow Cytometry}

Single-cell suspensions obtained from the bone marrow, spleen, or liver were first treated with Fc receptor block (2-4G2) and then surface stained. Fluorochrome-conjugated antibodies used in this study include antibodies against Sca-1 (D7), c-kit (2B8), NK1.1

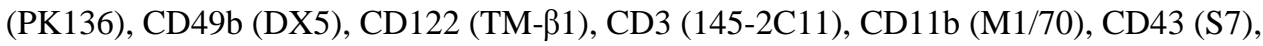
CD27 (LG.7F9), NKp46 (29A1.4), CD45.1 (A20), CD45.2 (104), Ly49C/I (5E6), Ly49D (4E5), Ly49H (3D10), NKG2A (20d5), NKG2D (CX5), and CD94 (18d3). Antibodies were purchased either from BD Bioscience, eBioescience, or Biolegends. Cells were analyzed on FACSCanto or LSRII flow cytometers (BD Bioscience), and the data were analyzed using FlowJo software (Tree Star). When indicated, cell sorting was performed on FACSAria High-Speed Cell Sorter at the flow cytometry core facility (University of Michigan).

\section{BrdU Incorporation and Revelation}

$\mathrm{CD} 11 \mathrm{c} \mathrm{dnR}^{\mathrm{and}}$ wild-type mice were treated (i.p.) with $3 \mathrm{mg} \mathrm{BrdU}$ (bromodeoxyuridine; Sigma) provided twice a day for 3 consecutive days. BrdU incorporation was revealed using BrdU Flow kit according to manufacturer protocol (BD Bioscience). Briefly, cells were first surface labeled, permeabilized and fixed in BD Cytofix/Cytoperm buffer for $30 \mathrm{~min}$ at $4^{\circ} \mathrm{C}$, then subjected to DNase I digestion for $1 \mathrm{~h}$ at $37^{\circ} \mathrm{C}$, and finally stained with FITCconjugated BrdU-specific antibody. Cells were analyzed on FACSCanto (BD Bioscience), and frequency of cycling cells was determined using FlowJo software (Tree Star). For experiments conducted at the early life stage, infant $\mathrm{CD} 11 \mathrm{c}^{\mathrm{dnR}}$ and wild-type mice were treated (i.p.) with $1 \mathrm{mg} \mathrm{BrdU}$ provided $3 \mathrm{~h}$ before mice sacrifice, and BrdU incorporation was revealed as described above. 


\section{Quantitative Gene Expression}

Bone marrow cells were isolated from CD11 $c^{\mathrm{dnR}}$ and wild-type mice and NK cells were sorted at different stages of development (stages D-F) using BD-Biosciences FACSAria. RNA was prepared using RNeasy Micro kit (Qiagen); cDNA was obtained using the standard protocol of reverse transcription; and quantitative gene expression (qPCR) was conducted on an ABI Prism 7900 instrument (Applied Biosystems). For cell cycle genes, we used a customized cell cycle qPCR array according to the manufacturer's instructions (Lonza), and data were analyzed using Global Pattern Recognition analytical software (Lonza). For transcription factor genes, we used SYBR Green qPCR, and data were analyzed using 2-33C3 method. Results were expressed as a fold of change in NK cells from CD11c ${ }^{\mathrm{dnR}}$ versus wild-type mice.

\section{Mouse Infection and Virus Titration}

Smith strain of MCMV was obtained from ATCC (American Type Culture Collection), and virus stock was produced by two passages in salivary glands of 3 week-old BALB/c mice, as previously described ${ }^{48}$. At $17-19$ days of age, $\mathrm{CD} 11 \mathrm{c}^{\mathrm{dnR}}$ mice and wild-type littermates on C57BL/6 background were infected (i.p.) with 4,000 Plaque Forming Units (PFU) of MCMV. Five days post-infection, spleens and livers were harvested and viral titers were determined by standard plaque assay using BALB/c mouse embryonic fibroblast monolayers ${ }^{48}$. Viral titers were expressed as MCMV $\log _{10}$ PFU per weight of tissue. Mice were monitored daily for morbidity.

\section{Statistics}

GraphPad Prism software was used to conduct unpaired, two-tailed Student's $t$ tests for sample analysis. Results with $P<0.05$ were considered significant.

\section{Supplementary Material}

Refer to Web version on PubMed Central for supplementary material.

\section{Acknowledgments}

We thank A. Laouar (Child Health Institute of New Jersey) for critical reading of the manuscript; I. Maillard for OP9 cell line; D. Kovarcik and B. Oliver (Lonza) for assistance with gene expression analysis; and the flow cytometry core facility for cell sorting. Supported by the National Institute of Health (T32 AI007413-17 to K.S. and R01 AI083642 to Y.L.).

\section{References}

1. Biron CA, Brossay L. NK cells and NKT cells in innate defense against viral infections. Curr Opin Immunol. 2001; 13:458-464. [PubMed: 11498302]

2. Lanier LL. NK cell recognition. Annu Rev Immunol. 2005; 23:225-274. [PubMed: 15771571]

3. Yokoyama WM, Kim S. How do natural killer cells find self to achieve tolerance? Immunity. 2006; 24:249-257. [PubMed: 16546094]

4. Kagi D, et al. Cytotoxicity mediated by $\mathrm{T}$ cells and natural killer cells is greatly impaired in perforin-deficient mice. Nature. 1994; 369:31-37. [PubMed: 8164737] 
5. Heusel JW, Wesselschmidt RL, Shresta S, Russell JH, Ley TJ. Cytotoxic lymphocytes require granzyme B for the rapid induction of DNA fragmentation and apoptosis in allogeneic target cells. Cell. 1994; 76:977-987. [PubMed: 8137431]

6. Fehniger TA, et al. Acquisition of murine NK cell cytotoxicity requires the translation of a preexisting pool of granzyme B and perforin mRNAs. Immunity. 2007; 26:798-811. [PubMed: 17540585]

7. Stetson DB, et al. Constitutive cytokine mRNAs mark natural killer (NK) and NK T cells poised for rapid effector function. J Exp Med. 2003; 198:1069-1076. [PubMed: 14530376]

8. Di Santo JP. Natural killer cell developmental pathways: a question of balance. Annu Rev Immunol. 2006; 24:257-286. [PubMed: 16551250]

9. Rosmaraki EE, et al. Identification of committed NK cell progenitors in adult murine bone marrow. Eur J Immunol. 2001; 31:1900-1909. [PubMed: 11433387]

10. Fathman JW, et al. Identification of the earliest natural killer cell-committed progenitor in murine bone marrow. Blood. 118:5439-5447. [PubMed: 21931117]

11. Kim S, et al. In vivo developmental stages in murine natural killer cell maturation. Nat Immunol. 2002; 3:523-528. [PubMed: 12006976]

12. Dorfman JR, Raulet DH. Acquisition of Ly49 receptor expression by developing natural killer cells. J Exp Med. 1998; 187:609-618. [PubMed: 9463411]

13. Vosshenrich CA, et al. Roles for common cytokine receptor gamma-chain-dependent cytokines in the generation, differentiation, and maturation of NK cell precursors and peripheral NK cells in vivo. J Immunol. 2005; 174:1213-1221. [PubMed: 15661875]

14. Townsend MJ, et al. T-bet regulates the terminal maturation and homeostasis of NK and Valpha14i NKT cells. Immunity. 2004; 20:477-494. [PubMed: 15084276]

15. Samson SI, et al. GATA-3 promotes maturation, IFN-gamma production, and liver-specific homing of NK cells. Immunity. 2003; 19:701-711. [PubMed: 14614857]

16. Taki S, Nakajima S, Ichikawa E, Saito T, Hida S. IFN regulatory factor-2 deficiency revealed a novel checkpoint critical for the generation of peripheral NK cells. J Immunol. 2005; 174:60056012. [PubMed: 15879093]

17. Lacorazza HD, et al. The ETS protein MEF plays a critical role in perforin gene expression and the development of natural killer and NK-T cells. Immunity. 2002; 17:437-449. [PubMed: 12387738]

18. Kataoka TR, Komazawa N, Oboki K, Morii E, Nakano T. Reduced expression of IL-12 receptor beta2 and IL-18 receptor alpha genes in natural killer cells and macrophages derived from B6mi/mi mice. Lab Invest. 2005; 85:146-153. [PubMed: 15492754]

19. Kaisho T, et al. Impairment of natural killer cytotoxic activity and interferon gamma production in CCAAT/enhancer binding protein gamma-deficient mice. J Exp Med. 1999; 190:1573-1582. [PubMed: 10587348]

20. Guilmot A, Hermann E, Braud VM, Carlier Y, Truyens C. Natural killer cell responses to infections in early life. J Innate Immun. 2011; 3:280-288. [PubMed: 21411972]

21. Le Garff-Tavernier M, et al. Human NK cells display major phenotypic and functional changes over the life span. Aging Cell. 2010; 9:527-535. [PubMed: 20477761]

22. Uksila J, Lassila O, Hirvonen T, Toivanen P. Development of natural killer cell function in the human fetus. J Immunol. 1983; 130:153-156. [PubMed: 6847879]

23. Dalle JH, et al. Characterization of cord blood natural killer cells: implications for transplantation and neonatal infections. Pediatr Res. 2005; 57:649-655. [PubMed: 15718362]

24. Wang Y, et al. High expression of NKG2A/CD94 and low expression of granzyme B are associated with reduced cord blood NK cell activity. Cell Mol Immunol. 2007; 4:377-382. [PubMed: 17976318]

25. Bukowski JF, Warner JF, Dennert G, Welsh RM. Adoptive transfer studies demonstrating the antiviral effect of natural killer cells in vivo. J Exp Med. 1985; 161:40-52. [PubMed: 2981954]

26. Laouar Y, Sutterwala FS, Gorelik L, Flavell RA. Transforming growth factor-beta controls T helper type 1 cell development through regulation of natural killer cell interferon-gamma. Nat Immunol. 2005; 6:600-607. [PubMed: 15852008] 
27. Williams NS, et al. Differentiation of NK1.1+, Ly49+ NK cells from flt3+ multipotent marrow progenitor cells. J Immunol. 1999; 163:2648-2656. [PubMed: 10453005]

28. Hayakawa Y, Smyth MJ. CD27 dissects mature NK cells into two subsets with distinct responsiveness and migratory capacity. J Immunol. 2006; 176:1517-1524. [PubMed: 16424180]

29. Walzer T, et al. Identification, activation, and selective in vivo ablation of mouse NK cells via NKp46. Proc Natl Acad Sci U S A. 2007; 104:3384-3389. [PubMed: 17360655]

30. Bousset K, Diffley JF. The Cdc7 protein kinase is required for origin firing during $\mathrm{S}$ phase. Genes Dev. 1998; 12:480-490. [PubMed: 9472017]

31. Xiong Y, et al. p21 is a universal inhibitor of cyclin kinases. Nature. 1993; 366:701-704. [PubMed: 8259214]

32. Gorelik L, Flavell RA. Transforming growth factor-beta in T-cell biology. Nat Rev Immunol. 2002; 2:46-53. [PubMed: 11905837]

33. Strunk T, Currie A, Richmond P, Simmer K, Burgner D. Innate immunity in human newborn infants: prematurity means more than immaturity. J Matern Fetal Neonatal Med. 2011; 24:25-31. [PubMed: 20569168]

34. Futata EA, Fusaro AE, de Brito CA, Sato MN. The neonatal immune system: immunomodulation of infections in early life. Expert Rev Anti Infect Ther. 2012; 10:289-298. [PubMed: 22397563]

35. Adkins B, Leclerc C, Marshall-Clarke S. Neonatal adaptive immunity comes of age. Nat Rev Immunol. 2004; 4:553-564. [PubMed: 15229474]

36. Hall WG, Browde JA Jr. The ontogeny of independent ingestion in mice: or, why won't infant mice feed? Dev Psychobiol. 1986; 19:211-222. [PubMed: 3709976]

37. Sundstrom Y, et al. The expression of human natural killer cell receptors in early life. Scand J Immunol. 2007; 66:335-344. [PubMed: 17635811]

38. Sun JC, Beilke JN, Lanier LL. Adaptive immune features of natural killer cells. Nature. 2009; 457:557-561. [PubMed: 19136945]

39. Dokun AO, et al. Specific and nonspecific NK cell activation during virus infection. Nat Immunol. 2001; 2:951-956. [PubMed: 11550009]

40. Raulet DH. Interplay of natural killer cells and their receptors with the adaptive immune response. Nat Immunol. 2004; 5:996-1002. [PubMed: 15454923]

41. Massague J. TGF-beta signal transduction. Annu Rev Biochem. 1998; 67:753-791. [PubMed: 9759503]

42. Alexandrow MG, Moses HL. Transforming growth factor beta and cell cycle regulation. Cancer Res. 1995; 55:1452-1457. [PubMed: 7882352]

43. Su HC, Ishikawa R, Biron CA. Transforming growth factor-beta expression and natural killer cell responses during virus infection of normal, nude, and SCID mice. J Immunol. 1993; 151:48744890. [PubMed: 8409446]

44. Su HC, Leite-Morris KA, Braun L, Biron CA. A role for transforming growth factor-beta 1 in regulating natural killer cell and $\mathrm{T}$ lymphocyte proliferative responses during acute infection with lymphocytic choriomeningitis virus. J Immunol. 1991; 147:2717-2727. [PubMed: 1918986]

45. Godfrey WR, et al. Cord blood CD4(+)CD25(+)-derived T regulatory cell lines express FoxP3 protein and manifest potent suppressor function. Blood. 2005; 105:750-758. [PubMed: 15374887]

46. Takahata Y, et al. CD25+CD4+ T cells in human cord blood: an immunoregulatory subset with naive phenotype and specific expression of forkhead box p3 (Foxp3) gene. Exp Hematol. 2004; 32:622-629. [PubMed: 15246158]

47. Randall TD, Weissman IL. Phenotypic and functional changes induced at the clonal level in hematopoietic stem cells after 5-fluorouracil treatment. Blood. 1997; 89:3596-3606. [PubMed: 9160664]

48. Fodil-Cornu N, Pyzik M, Vidal SM. Use of inbred mouse strains to map recognition receptors of MCMV infected cells in the NK cell gene locus. Methods Mol Biol. 2010; 612:393-409. [PubMed: 20033656] 

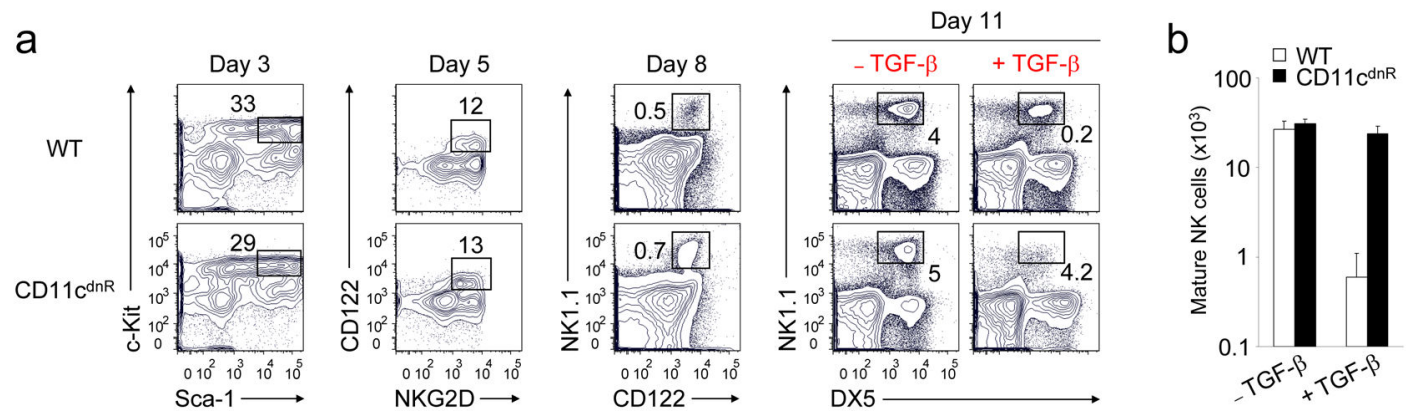

Figure 1. TGF- $\beta$ is a negative regulator of NK cell generation CD11 $c^{\mathrm{dnR}}$ and wild-type mice were injected (i.p.) with 5-FU. Four days later, mice were sacrificed and HSC-enriched bone marrow cells were cultured in the presence of IL-7, SCF, and Flt3L. On day 5, cells were harvested, plated on OP9 stromal cells, and cultured in the presence of IL-15. On day 8, cultures were supplemented with or without TGF- $\beta$ and outcomes on NK cell production were determined on day 11. (a) FACS plots are from gated $\mathrm{CD}^{-}$cells, and numbers indicate frequency of $\mathrm{HSC}\left(\mathrm{c}-\mathrm{kit}^{+} \mathrm{Sca}-1^{+}\right), \mathrm{NK}$ cell precursors $\left(\mathrm{CD} 122^{+} \mathrm{NKG} 2 \mathrm{D}^{+}\right)$, immature $\left(\mathrm{NK} 1.1^{+} \mathrm{CD} 122^{+}\right)$, and mature $\left(\mathrm{NK} 1.1^{+} \mathrm{DX} 5^{+}\right) \mathrm{NK}$ cells. (b) Histograms indicate numbers of mature NK cells $\left(\mathrm{CD} 3^{-} \mathrm{NK} 1.1^{+} \mathrm{DX} 5^{+}\right)$from $\mathrm{CD} 11 \mathrm{c}^{\mathrm{dnR}}$ (black bar) and wild type (white bar) cultures produced in the absence versus the presence of TGF- $\beta$. Data in $\mathbf{a}, \mathbf{b}$ are representative of two independent experiments with $n=3$ mice per experiment. 

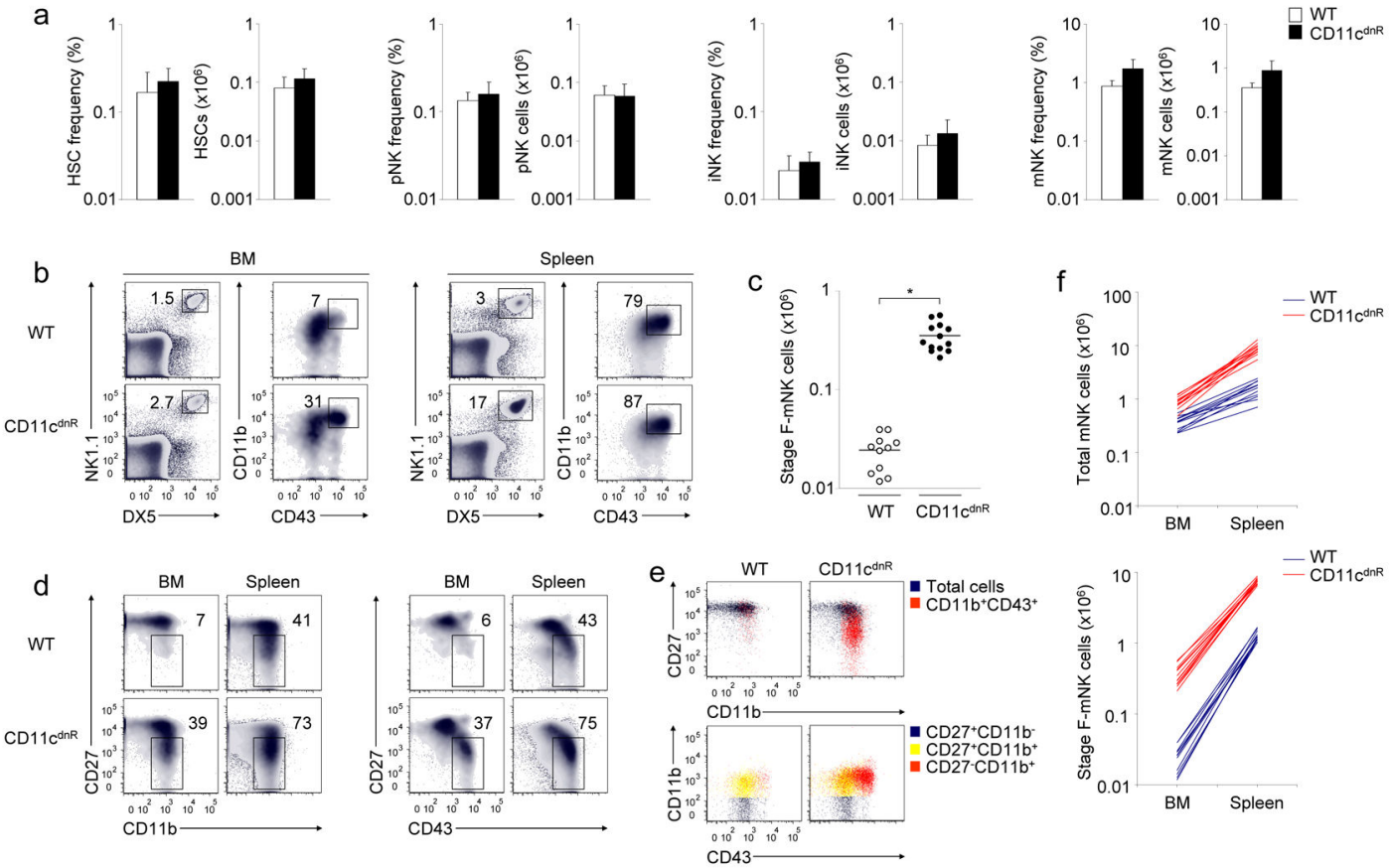

Figure 2. CD11 $\mathrm{c}^{\mathrm{dnR}}$ mice produce high numbers of stage $\mathrm{F}$-mNK cells

(a) Histograms indicate frequency and numbers of HSC, pNK, iNK, and mNK cells from the bone marrow of CD11 $c^{\mathrm{dnR}}$ (solid bar) versus wild type (open bar) mice. (b) FACS plots are from gated $\mathrm{CD}^{-}$cells and numbers indicate frequency of $\mathrm{mNK}$ cells. Distribution of $\mathrm{CD} 11 \mathrm{~b}$ versus $\mathrm{CD} 43$ is from gated $\mathrm{mNK}$ cells and numbers indicate frequency of stage FmNK cells $\left(\mathrm{CD} 11 \mathrm{~b}^{+} \mathrm{CD} 43^{+}\right)$. (c) Graph shows numbers of stage F-mNK cells in the bone marrow of CD11 ${ }^{\mathrm{dnR}}$ (black circle) versus wild type (white circle) mice. *, $p<0.005$ (Student's $t$-test). (d) FACS plots are from gated mNK cells, and numbers indicate frequency of stage F-mNK cells as identified by $\mathrm{CD} 27^{-} \mathrm{CD} 11 \mathrm{~b}^{+}$and $\mathrm{CD} 27^{-} \mathrm{CD} 43^{+}$ phenotypes. (e) FACS plots show overlay of NK cell subsets in the bone marrow. Upper panels show overlay of $\mathrm{CD} 11 \mathrm{~b}^{+} \mathrm{CD} 43^{+} \mathrm{mNK}$ cells (red dots) versus total $\mathrm{mNK}$ cells (blue dots). Lower panels show overlay of $\mathrm{CD} 27^{+} \mathrm{CD} 11 \mathrm{~b}^{-}$(blue dots), $\mathrm{CD} 27^{+} \mathrm{CD} 11 \mathrm{~b}^{+}$(yellow dots), and $\mathrm{CD} 27^{-} \mathrm{CD} 11 \mathrm{~b}^{+}$(red dots) $\mathrm{mNK}$ cell subsets. (f) Graphs show numbers of total mNK cells and stage F-mNK cells in the bone marrow versus spleen of CD11 $c^{\mathrm{dnR}}$ (red line) versus wild type (blue line) mice. Data in $\mathbf{a}, \mathbf{b}$ and $\mathbf{d}, \mathbf{e}$ are representative of three independent experiments with $n=8$ and 3 mice, respectively. Results in $\mathbf{c , f}$ are representative four independent experiments with $n=11 \mathrm{WT}$ and $13 \mathrm{CD} 11 \mathrm{c}^{\mathrm{dnR}}$ mice. 
a

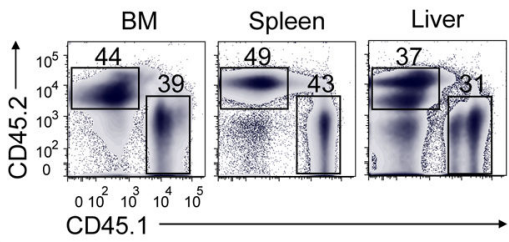

donor cells
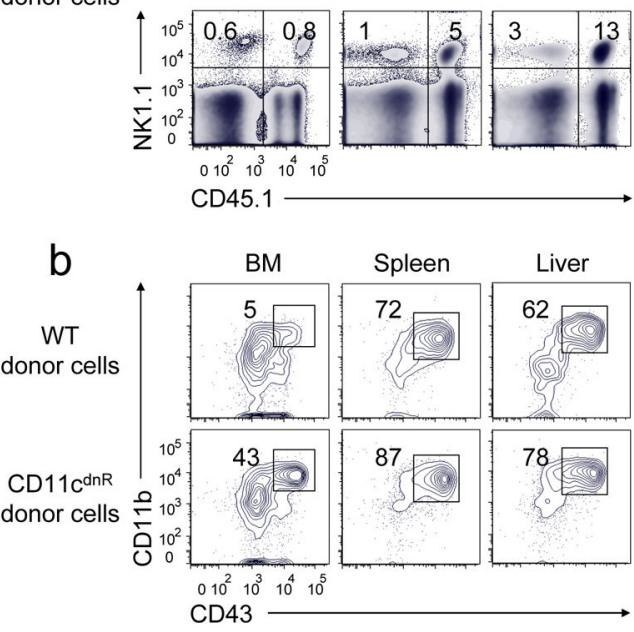

C

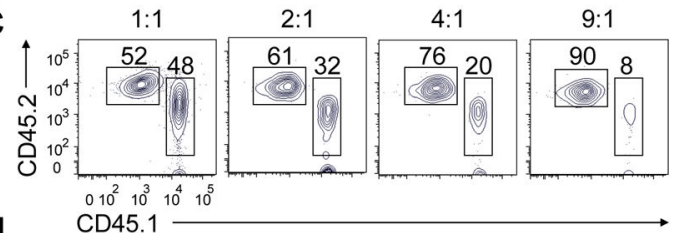

d

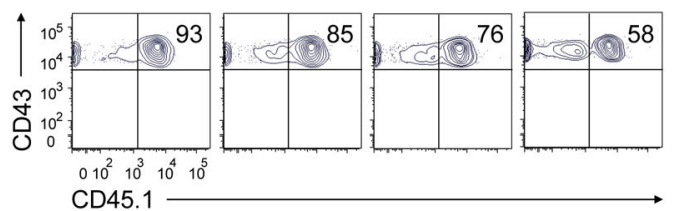

e

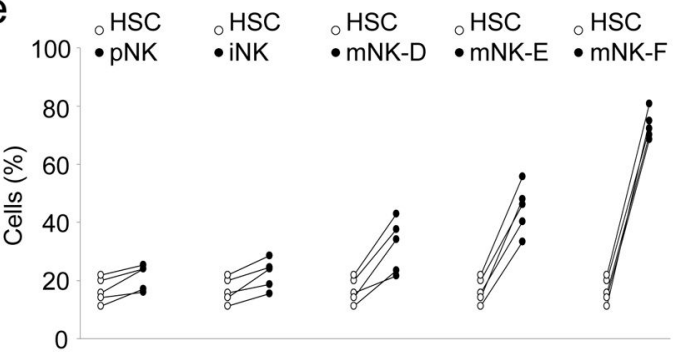

Figure 3. Massive production of stage F-mNK cells in CD11 $c^{\mathrm{dnR}}$ mice is cell autonomous (a-b) Mixed bone marrow chimeras were constructed with wild type (CD45.2) and $\mathrm{CD} 11 \mathrm{c}^{\mathrm{dnR}}(\mathrm{CD} 45.1)$ donor bone marrow cells provided in the inoculum at 1:1 ratio. Six weeks later, chimeras were sacrificed and donor-derived NK cells were analyzed in the bone marrow, spleen, and liver. (a) FACS plots show the distribution of CD45.2 versus CD45.1 in each organ. NK1.1 versus CD45.1 staining is from gated $\mathrm{CD}^{-}$cells and numbers indicate frequency of NK cells from each donor. (b) Distribution of CD11b versus CD43 is from gated $\mathrm{mNK}$ cells that were gated from wild type $\left(\mathrm{CD} 45.2^{+}\right)$or $\mathrm{CD} 11 \mathrm{c}^{\mathrm{dnR}}\left(\mathrm{CD} 45.1^{+}\right)$donor cells. Numbers indicate frequency of stage F-mNK cells produced from each donor. Data in $\mathbf{a}, \mathbf{b}$ are representative of two independent experiments with $n=3$ chimeras per experiment. (c-e) Mixed bone marrow chimeras were constructed with wild type (CD45.2) and CD11 $\mathrm{c}^{\mathrm{dnR}}(\mathrm{CD} 45.1)$ donor bone marrow cells provided in the inoculum at 1:1, 2:1, 4:1, and 9:1 ratios. Six weeks later, chimeras were sacrificed and donor-derived NK cells were analyzed in the bone marrow at different stages of development. (c) FACS plots show the distribution of CD45.1 versus CD45.2 in the bone marrow. (d) FACS plots are from gated $\mathrm{CD} 11 \mathrm{~b}^{+} \mathrm{CD} 43^{+} \mathrm{mNK}$ cells and numbers indicate the frequency of CD11 $\mathrm{c}^{\mathrm{dnR}}\left(\mathrm{CD} 45.1^{+}\right)$ origin among stage F-mNK cells. (e) Graph shows the frequency of CD11 $\mathrm{c}^{\mathrm{dnR}}\left(\mathrm{CD} 45.1^{+}\right)$ origin among HSCs, pNK, iNK, and mNK cells at stages D, E, and F. Results in e are from 4:1 chimeras group. Data in $\mathbf{c}, \mathbf{e}$ are representative of two independent experiments with $n=$ 5 mice per chimeras group. 
a

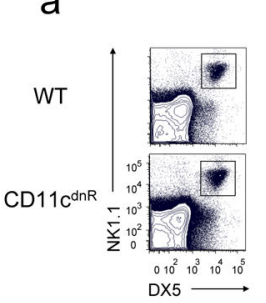

C 60

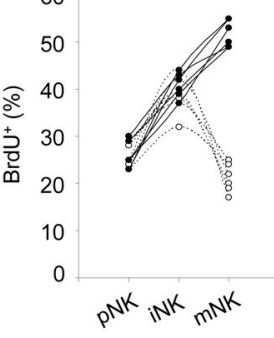

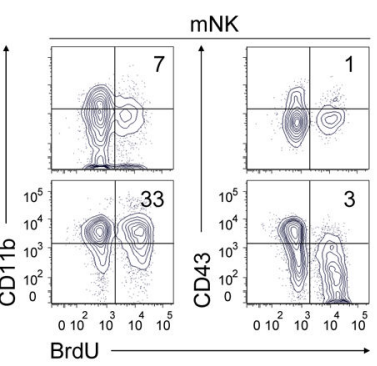

d

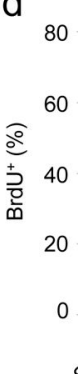

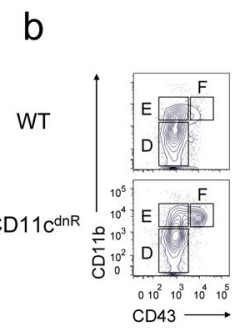

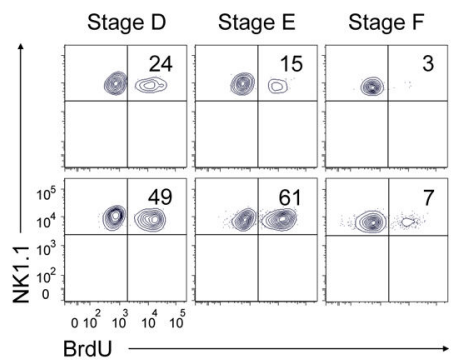

e

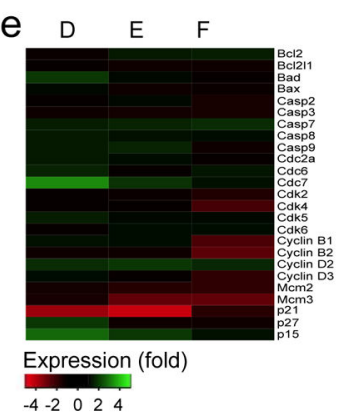

Figure 4. TGF- $\beta$ arrests NK cell cycle at stages $D / E$ and limits NK cell transition at stage $F$ (a-d) CD11 $c^{\mathrm{dnR}}$ and wild type mice were injected (i.p.) twice a day with BrdU for 3 days. On day 3 , mice were sacrificed and frequency of cycling cells was determined in the bone marrow. (a-b) FACS plots show the distribution of BrdU staining among total mNK cells (a) and gated $\mathrm{mNK}$ cells at stages $\mathrm{D}, \mathrm{E}$, and $\mathrm{F}(\mathbf{b})$. (c) Graph shows the frequency of cycling cells in $\mathrm{pNK}$, iNK, and $\mathrm{mNK}$ cells from CD11 $\mathrm{c}^{\mathrm{dnR}}$ (black circle) versus wild type (white circle) mice. (d) Graph shows the frequency of cycling cells in mNK cells at stages D, E, and F from CD11 $c^{\mathrm{dnR}}$ (black circle) versus wild type (white circle) mice. Data in a,d are representative of three independent experiments with $n=2$ mice per experiment and results in c,d show all 6 individual mice. (e-f) mNK cells at stages D, E, and F were sorted from the bone marrow. mRNA was isolated and cDNA was subjected to pathway-specific qPCR for analysis of cell cycle genes (e) or SYBR Green qPCR for analysis of transcription factors Tbet, GATA-3, and IRF-2 (f). Data were analyzed using Global Pattern Recognition analytical software (e) or 2-33C3 method (f) and results were expressed as fold of change in CD11 $c^{\mathrm{dnR}}$ versus wild type samples. Data in e,f are representative of three independent cell sorting with samples pooled from $n=12 \mathrm{CD} 11 \mathrm{c}^{\mathrm{dnR}}$ and 25 WT mice. 

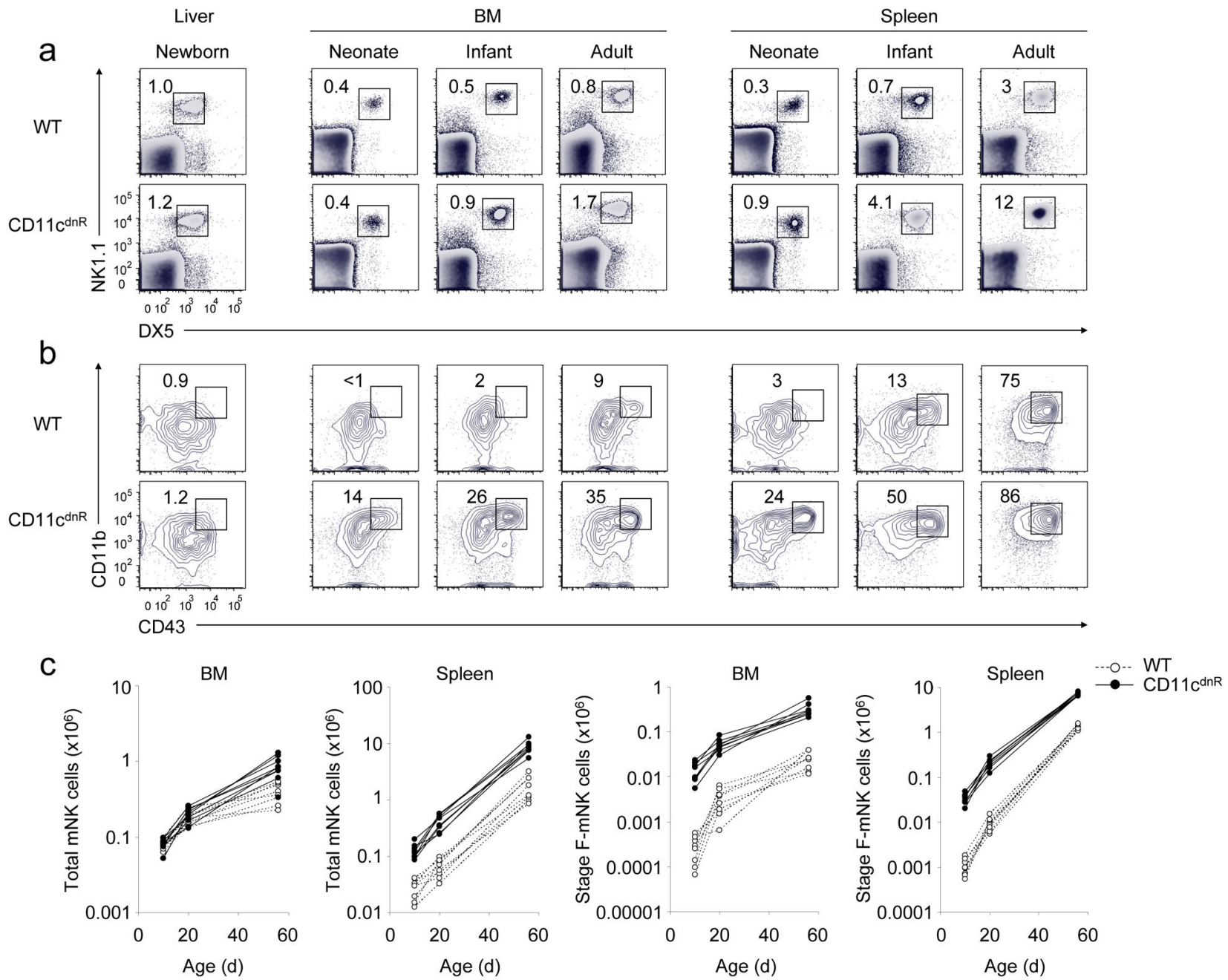

Figure 5. TGF- $\beta$ imposes constraints on NK cell maturation during ontogeny

NK cells from CD11 $c^{\mathrm{dnR}}$ and wild type mice were analyzed in newborns (0-2 days), neonates (7-10 days), infants (17-20 days), and adults (56-84 days). (a) FACS plots show NK1.1 versus DX5 staining on gated $\mathrm{CD}^{-}{ }^{-}$cells, and numbers indicate the frequency of mNK cells as a function of age. (b) Distribution of CD11b versus CD43 is from gated mNK cells and numbers indicate the frequency of stage F-mNK cells as a function of age. (c) Graphs show numbers of total mNK cells and stage F-mNK cells as a function of age in bone marrow and spleen of $\mathrm{CD} 11 \mathrm{c}^{\mathrm{dnR}}$ (black circle) versus wild type (white circle) mice. Data in $\mathbf{a}, \mathbf{b}$ are representative of two independent experiments with $n=4$ newborn mice and four independent experiments with $n=8$ mice per age group (neonate, infant and adult age). Data in $\mathbf{c}$ are representative of four independent experiments with $n=8$ mice per age group (neonate, infant and adult age) and results show all 8 individual mice. 


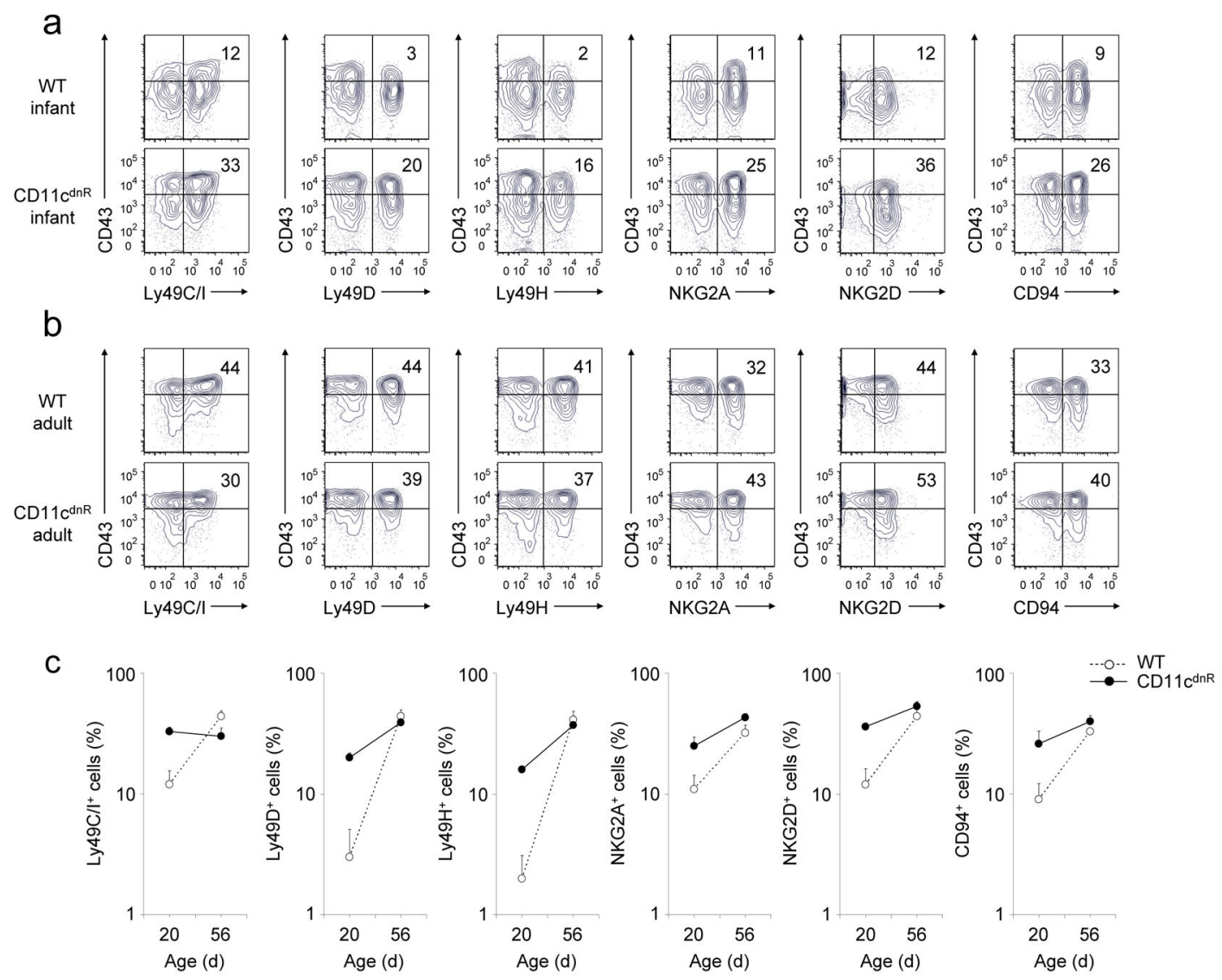

Figure 6. Infant CD11 $\mathrm{c}^{\mathrm{dnR}}$ mice have mature NK cell compartment

(a-b) FACS plots show distribution of CD43 versus NK cell receptors among gated $\mathrm{mNK}$ cells $\left(\mathrm{CD} 3^{-} \mathrm{NK} 1.1^{+} \mathrm{DX} 5^{+}\right)$, and numbers indicate frequency of terminally mature $\mathrm{Ly} 49 \mathrm{C} / \mathrm{I}^{+}$, $\mathrm{Ly}_{49 D^{+}}, \mathrm{Ly}_{49 \mathrm{H}^{+}}, \mathrm{NKG}_{2 \mathrm{~A}^{+}}, \mathrm{NKG}_{2} \mathrm{D}^{+}$, and $\mathrm{CD}^{+} 4^{+} \mathrm{mNK}$ cell subsets in CD11c $\mathrm{c}^{\mathrm{dnR}}$ and wild type mice at infant (17-20 days) and adult (56-84 days) ages. (c) Graphs show the frequency of stage F-mNK cell subsets $\left(\mathrm{CD} 43^{+} \mathrm{Ly} 49 \mathrm{C} / \mathrm{I}^{+}, \mathrm{CD} 43^{+} \mathrm{Ly}^{4} \mathrm{D}^{+}, \mathrm{CD} 43^{+} \mathrm{Ly}_{49 \mathrm{H}^{+}}\right.$,

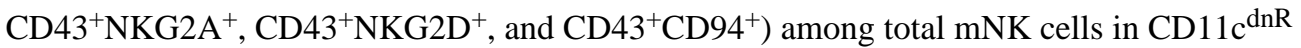
(black circle) versus wild type (white circle) at infant versus adult ages. Data in a,c are representative of three independent experiments with $n=4$ infant and 8 adult mice. 

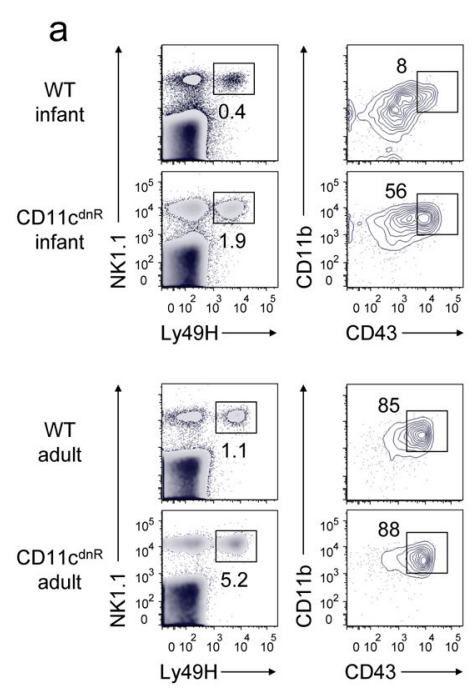
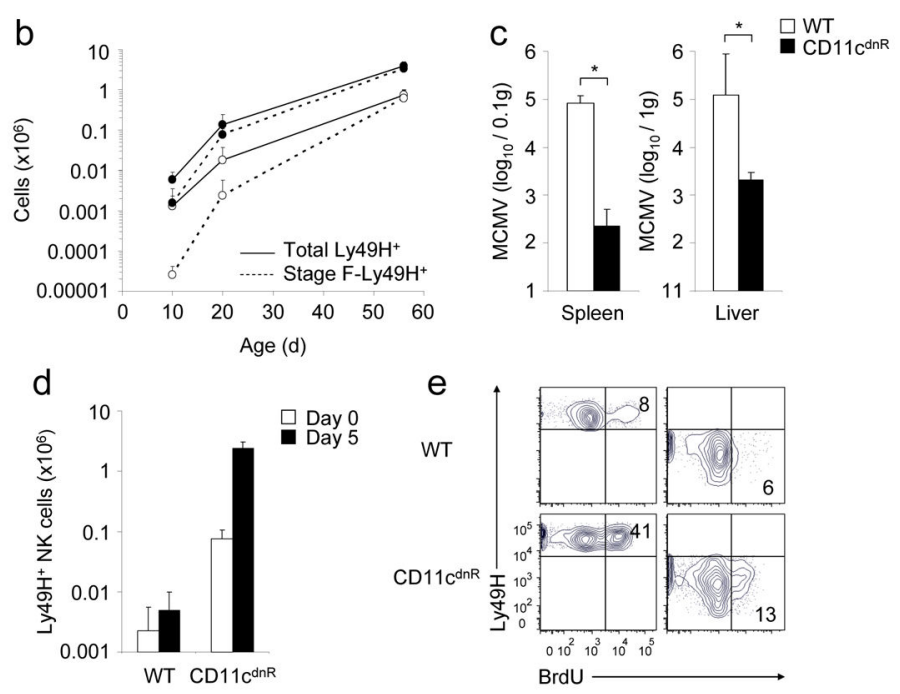

Figure 7. Infant $C_{D 11} \mathrm{c}^{\mathrm{dnR}}$ mice are protected from MCMV infection

(a) FACS plots are from gated $\mathrm{CD}^{-}$cells and numbers indicate the frequency of $\mathrm{Ly}^{4} 9 \mathrm{H}^{+}$ NK cells in the spleen of CD11 $\mathrm{c}^{\mathrm{dnR}}$ and wild type mice at infant (17-20 days) versus adult (56-84 days) ages. Distribution of CD11b versus CD43 is from gated $\mathrm{Ly} 49 \mathrm{H}^{+} \mathrm{NK}$ cells and numbers indicate the frequency of stage F-Ly $49 \mathrm{H}^{+} \mathrm{NK}$ cells in the spleen. (b) Graph shows numbers of total $\mathrm{Ly} 49 \mathrm{H}^{+} \mathrm{NK}$ cells (solid line) versus stage $\mathrm{F}-\mathrm{Ly} 49 \mathrm{H}^{+} \mathrm{NK}$ cells (dashed line) in the spleen of $\mathrm{CD} 11 \mathrm{c}^{\mathrm{dnR}}$ (black circle) versus wild type (white circle) mice as a function of age. Data in $\mathbf{a}, \mathbf{b}$ are representative of three independent experiments with $n=3$ infant and 6 adult mice. (c-e) CD11 $\mathrm{c}^{\mathrm{dnR}}$ and wild type infant mice (17-20 days) under pure C57BL/6 background were infected with MCMV and analyzed 5 days post-infection. (c) Histograms show viral load in spleens and livers from infected CD11 $\mathrm{c}^{\mathrm{dnR}}$ (black bar) versus wild type (white bar) infant mice. ${ }^{*}, p$ values $<0.0001$. (d) Histograms show numbers of Ly49H $\mathrm{H}^{+} \mathrm{NK}$ cells in the spleen before (white bar) and 5 days after (black bar) MCMV infection. (f) On day 5 post-infection, mice were injected (i.p.) with BrdU, and cell proliferation was analyzed in the spleen 3-4 hrs later. FACS plots show the distribution of BrdU staining among gated $\mathrm{Ly}_{49 \mathrm{H}^{+}}$versus $\mathrm{Ly} 49 \mathrm{H}^{-} \mathrm{NK}$ cells. Data in $\mathbf{c}, \mathbf{e}$ are representative of two independent experiments with $n=3 \mathrm{CD} 11 \mathrm{c} \mathrm{dnR}^{\mathrm{d}}$ and $6 \mathrm{WT}$ infant mice. 